\title{
Polymerase Chain Reaction and blood culture for diagnosis of canine sepsis
}

\author{
Marcelo Marques da Silveira ${ }^{1^{*}}$ (2) Stéfhano Luis Cândido ${ }^{1}$ Karin Rinaldi dos Santos ${ }^{2}$ \\ Maerle Oliveira Maia ${ }^{1}$ Roberto Lopes de Souza $^{2}$ Valéria Régia Franco Sousa ${ }^{3}$ \\ Arleana do Bom Parto Ferreira de Almeida ${ }^{3}$ Valeria Dutra ${ }^{1}$ Luciano Nakazato $^{1}$
}

${ }^{1}$ Laboratório de Microbiologia Veterinária e Biologia Molecular Veterinária, Universidade Federal de Mato Grosso (UFMT), Av. Fernando Corrêa, s/n, 78060-900, Coxipó, Cuiabá, MT, Brasil. E-mail: celo_medvet@hotmail.com."Corresponding author. ${ }^{2}$ Clínica Cirúrgica de Pequenos Animais, Hospital Veterinário, Universidade Federal de Mato Grosso (UFMT), Coxipó, Cuiabá, MT, Brasil. ${ }^{3}$ Clínica Médica de Pequenos Animais, Hospital Veterinário, Universidade Federal de Mato Grosso (UFMT), Coxipó, Cuiabá, MT, Brasil.

ABSTRACT: Sepsis is characterized by the presence of organ dysfunction secondary to the dysregulated systemic inflammatory response associated with an infection, and has high mortality rates. Traditional diagnostic techniques based on non-microbiological isolation are time-consuming and may delay treatment. Thus, this study aimed to compare bacterial and fungal broad-range polymerase chain reaction (PCR) and blood culture for diagnosis of sepsis in dogs. Blood samples from 88 dogs with suspected sepsis were analyzed by blood culture, and PCR to detect bacterial and fungal DNA. On blood culture, 20 (22.7\%) samples tested positive for bacterial isolates; however, none tested positive for fungi. Through PCR analysis, bacterial DNA was detected in 46 (52.3\%) animals, whereas fungal DNA was present in one (1.1\%) sample. Our results showed that PCR-based testing has important diagnostic value for canine blood infections because it has a shorter turnaround time and higher sensitivity than traditional blood culture. Key words: blood culture, PCR, bacteremia, fungemia.

\section{Reação em Cadeia da Polimerase e hemocultura para diagnóstico de sepse canina}

RESUMO: Sepse se caracteriza pela presença de disfunção orgânica secundária à resposta inflamatória sistêmica desregulada, associada a uma infecção com elevadas taxas de mortalidade. As técnicas tradicionais baseadas no isolamento microbiológico são demoradas e podem atrasar o tratamento. O objetivo deste estudo foi comparar a Reação em Cadeia da Polimerase (PCR) bacteriana e fúngica e hemocultura em cães com sepse. Foram analisadas 88 amostras de sangue de cães com suspeita de sepse por meio de hemocultura e PCR para detectar DNA bacteriano e fúngico. Nas culturas sanguineas, 20 (22,7\%) amostras foram positivas para isolados bacterianos. No entanto, nenhuma amostra foi positiva para fungos. Através da análise por PCR, o DNA bacteriano foi detectado em 46 animais (52,3\%), enquanto que o DNA fúngico estava presente em uma amostra (1,1\%). Neste caso, a PCR apresenta importante valor diagnóstico em cães com infeções sanguíneas devido a sua rapidez e maior sensibilidade do que a isolamento por hemocultura.

Palavras-chave: Hemocultura, PCR, bacteremia, fungemia.

\section{INTRODUCTION}

Sepsis in dogs is associated with a poor prognosis and a high mortality rate, and hence requires immediate intervention (HEILMANN et al., 2013). It is characterized by bloodstream infections resulting in systemic inflammatory response syndrome (SIRS) and organ dysfunction involving the cardiorespiratory, respiratory, hepatic, or renal systems (SINGER et al., 2016).

Blood culture is the gold standard for diagnosis of bloodstream infection that provides information about the etiology of the infection; however, its value as a diagnostic test is limited due to its low sensitivity, long turnaround time, and limited application in patients who have received antibiotic therapy (HEILMANN et al., 2013). Thus, attempts have been made to develop alternative diagnostic techniques, such as polymerase chain reaction (PCR), with a short turnaround time and high sensitivity (PAOLUCCI et al., 2010; MEURS et al., 2011; HEILMANN et al., 2013). In this study, we reviewed cases of canine sepsis at a veterinary hospital, and compared blood culture with broadrange PCR techniques in terms of their application for diagnosis of bloodstream infection in dogs and detection of antibiotic resistance in isolates.

Blood samples were collected from 88 dogs with suspected sepsis between March and December 2013. The inclusion criteria (Table 1) 
Table 1 - Criteria to diagnose of systemic inflammatory response syndrome (SIRS) in dogs.

\begin{tabular}{lc}
\hline Criteria & \\
\hline Tachypnea & Respiratory rate $>20$ per minute \\
\hline Tachycardia & Heart rate $>120$ \\
\hline Fever & Temperature $>39.2^{\circ} \mathrm{C}$ \\
Hypothermia & Temperature $<38.1^{\circ} \mathrm{C}$ \\
\hline Leucocytosis & $>16 \times 10^{3} / \mu \mathrm{L}$ \\
\hline Leucopenia & $<6 \times 10^{3} / \mu \mathrm{L}$ \\
\hline Increased band neutrophill with normal WBC & Band neutrophils $>3 \%$
\end{tabular}

used in this study were based on clinical suspicion and parameters of SIRS described by GREINER \& HARTMANN (2008).

The dogs were clipped and aseptically prepped. Two equal-volume blood samples were drawn simultaneously from the jugular and cephalic veins. The volume of each blood sample ranged from 2 to $5 \mathrm{~mL}$ depending on the weight of the animal and its clinical condition.

An aliquot of the blood in each sample was processed using a Hemobac trifásico pediátrico system $^{\circledR}$ (Chocolate Agar, MacConkey Agar, and Sabouraud Agar) and incubated aerobically at $37^{\circ} \mathrm{C}$ for up to 7 days. An animal was considered positive for a microbial agent only when the same agent was isolated from two samples drawn from the animal. Biochemical characterization was performed according to QUINN et al. (1994).

Five hundred microliters of blood was used for phenol-chloroform DNA extraction(SAMBROOK \& RUSSEL, 2001). PCR was performed using 27f (AGAGTTTGATCCTGGCTCAG) and 1492r (GGTTACCTTGTTACGACTT) universal primers for $16 \mathrm{~S}$ rDNA (bacteria), as described by LANE (1991), and internal transcribed sequences (ITSfungi) ITS-4 (TCCTCCGCTTATTGATATGC) and ITS-5 (GGAAGTAAAAGTCGTAACAAGG), as described by WHITE et al. (1990). Bacterial PCR mix had a final volume of $25 \mu \mathrm{L}$, which included 10 ng DNA, 1 UTaq DNA polymerase (Invitrogen), 0.2 $\mathrm{mM}$ of each dNTP, $2.5 \mathrm{mM} \mathrm{MgCl}_{2}, 1 \times$ PCR buffer, and 20 pmol of each primer. Reaction conditions were as follows: $94^{\circ} \mathrm{C}$ for $5 \mathrm{~min} ; 30$ cycles of $94^{\circ} \mathrm{C}$ for $45 \mathrm{~s}$, $63^{\circ} \mathrm{C}$ for $45 \mathrm{~s}$, and $72^{\circ} \mathrm{C}$ for $60 \mathrm{~s}$; and a final extension step of $72^{\circ} \mathrm{C}$ for $7 \mathrm{~min}$. Fungal PCR mix had the same volume and was processed using the same reaction conditions. Except concentration of $\mathrm{MgCl}_{2}$ that was $2.0 \mathrm{mM}$ and the annealing temperature/time was $53^{\circ} \mathrm{C} / 30 \mathrm{~s}$. Ultrapure water was used as a negative control, and DNA from Pasteurella multocida, Corynebacterium sp., and Aspergillus fumigatus (ATCC 204305) was used as a positive control. Five PCR-positive samples, that were hemoculture negative, were purified and subjected to DNA sequencing with the corresponding primers. The sequences obtained were analyzed using the BLAST program (<www.ncbi.nlm.nih.gov $>$ ). Descriptive statistics were used for all individual variables, and unweighted kappa tests were used for comparisons between the diagnostic tests.

The mean age of the dogs was 5.3 years (standard deviation $=4.5$ years), $70.4 \%(n=62)$ were female and $29.5 \%(n=26)$ male, and they belonged to 18 different breeds. The diagnoses included pyometra (37.5\%), urinary tract infection (16\%), pneumonia (11\%), cutaneous abscesses (7\%), and other causes $(28.5 \%)$ such as peritonitis, endocarditis, and open fractures.

On blood culture, 20 (22.7\%) dogs tested positive for microbial agents. Twenty-tree bacterial isolates were observed, namely, Staphylococcus sp. $(\mathrm{n}=9)$, Escherichia coli $(\mathrm{n}=7)$, Enterobacter $\mathrm{sp}$. $(\mathrm{n}=2)$, Micrococcus sp. $(\mathrm{n}=2)$, Streptococcus $\mathrm{sp}$. $(\mathrm{n}=1)$, Pseudomonas sp. $(\mathrm{n}=1)$, and Salmonella sp. $(n=1)$. From three dogs $(3.4 \%)$, two distinct bacteria were isolated. No fungal isolates were detected in blood cultures.

In the PCR analysis, 46 (52.3\%) dogs tested positive for bacteria and only $1(1.1 \%)$ for fungi. A comparison between results of the PCR analysis and blood culture showed a lack of concordance between the two tests (Table 2). The DNA sequences of samples that tested negative on the blood culture but positive on bacterial PCR showed identity with Candidatus mycoplasma haematoparvum (99\%), Anaplasma platys (99\%), Pseudomonas sp. (97\%), and Flavobacterium sp. (97\%). DNA sequences of 
Table 2 - Comparison of PCR (bacteria/fungi) and isolation technique results in dogs with suspected sepsis (Kappa test $=0.06$ [95\% CI, -0.14 to 0.25$])$

\begin{tabular}{lccc}
\hline & Blood culture positive & Blood culture negative & Total \\
PCRpositive & 12 & 35 & 47 \\
PCRNegative & 8 & 33 & 41 \\
Total & 20 & 68 & 88 \\
\hline
\end{tabular}

samples that tested positive on fungal PCR had $98 \%$ identity with Phoma sp.

Pyometra and urinary infection were the most common diagnoses. Similar studies conducted in the past have shown that these conditions are associated with a high risk of sepsis (HAUPTMAN et al., 1997). Blood culture had a low sensitivity, detecting only $22.7 \%$ of cases, however clinical conditions could interfere in results, since, in human, sepsis rates were different from septic shock $(50 \%)$, pneumonia $(30 \%)$ and overall condition (5-15\%), and in dog from pyometra (51.5\%) (KALENSKI et al., 2012).

In a previous study, more cases of sepsis are detected by PCR than by blood culture because of the high sensitivity of the former (LIESENFELD et al., 2014). Together with DNA sequencing, it can be used to complement identification of uncultivable, pernicious or slow-growing microorganisms (PAOLUCCI et al., 2010), such as Candidatus mycoplasma haematoparvum, Anaplasma platys and Phoma spp. that cause opportunistic infections in immunosuppressed dogs (CABAÑES et al., 1996; MESSICK 2004). Blood culture; however, is still necessary to determine the correct antibiotic therapy (PAOLUCCI et al., 2010) but some improvement as multiplex PCR could detect both bacteria DNA and resistance genes (mecA, vanA/B, and bla ${ }_{K P C}$ ) of sepsis in humans (SALIMNIA et al., 2016).

Thus, PCR allows for early diagnosis of sepsis and rapid treatment (antibacterial or antifungal), which lowers the treatment/hospital cost (LIESENFELD et al., 2014). Although, microbial DNA can be found even in healthy individuals, a previous study showed that the presence of microbial DNA in the blood of human patients with sepsis indicated a high risk of death (O’DWYER et al., 2017).

Sepsis in dogs is a life-threatening condition and thus diagnostic tools are important to determine a rapid treatment protocol. In this study, PCR testing was shown to have diagnostic value for canine blood infections because it has a shorter turnaround time and higher sensitivity than traditional blood culture.

\section{ACKNOWLEDGEMENTS}

We thank the Coordenação de Aperfeiçoamento de Pessoal de Nível Superior (CAPES) for financial support.

\section{BIOETHICS AND BIOSECURITY COMMITTEE APPROVAL}

All procedures were approved by the Ethics Committee for Animal Use UFMT 23108.015329/13-4.

\section{DECLARATION OF CONFLICTING INTERESTS}

We have no conflict of interest to declare.

\section{REFERENCES}

CABAÑES F.J., et al. Seasonal study of the fungal biota of the fur of dogs. Mycopathologia, v. 133: 1-7, 1996. Available from: $<$ https://link.springer.com/article/10.1007/BF00437092.> Accessed: Nov. 20, 2017.

GREINER G.M., HARTMANN K. A retrospective study of the clinical presentation of 140 dogs and 39 cats with bacteraemia. Journal of Small Animal Practice, v.49, p.378-383, 2008. : Available from: $<$ https://www.ncbi.nlm.nih.gov/pubmed/18422500 $>$. Accessed: Nov. 22, 2016. doi:10.1111/j.1748-5827.2008.00546.x.

HAUPTMAN J.G. et al. Evaluation of the sensivity and specificity of diagnostic criteria for sepsis in dogs. Veterinary Surgery, v. 26, p.393-397, 1997. Available from: <http://onlinelibrary.wiley.com/ doi/10.1111/j.1532-950X.1997.tb01699.x/abstract>. Accessed: Nov. 22, 2016. doi: 10.1111/j.1532-950X.1997.tb01699.x.

HEILMANN R.M. et al. Comparison of PCR and conventional blood culture to analyze blood from dogs with suspected sepsis. Veterinary Journal, v. 198, p.714-716, 2013. Available from: <http://www.sciencedirect.com/science/article/pii/ S1090023313005121?via\%3Dihub>. Accessed: Nov. 22, 2016. doi: 10.1016/j.tvj1.2013.10.001.

KALENSKI T.A. et al. Identificação das bactérias envolvidas na sepse grave de fêmeas caninas com piometra submetidas a ováriohisterectomia terapêutica. Brazilian Journal of Veterinary Research and Animal Science, v.49, p.130-138, 2012. Avalable from: <http://www.revistas.usp.br/bjvras/article/view/40269> .Accessed: Nov. 24, 2016. Doi:10.11606/issn.2318-3659. v49i2p130-138.

LANE, D.J. 16S/23S rRNA sequencing. In: STACKEBRANDT, E.; GOODFELLOW, M. (Ed.). Nucleic acid techniques in 
bacterial systematics. New York: John Wiley \& Sons, 1991. p.115-175. Available from: <https://www.ncbi.nlm.nih.gov/pmc/ articles/PMC99765/> .Accessed: Jan. 31, 2018.

LIESENFELD O. et al. Molecular diagnosis of sepsis: New aspects and recent developments. European Journal of Microbiology and Immunology, v.4, p.1-25, 2014. Available from: <https://www.ncbi.nlm.nih.gov/pmc/articles/ PMC3955828/>. Accessed: Nov. 22, 2016 doi:10.1556/ EuJMI.4.2014.1.1.

MESSICK J.B. Hemotrophic mycoplasmas (hemoplasmas): a review and new insights into pathogenic potential. Veterinary Clinical Pathology,v.22, p2-13, 2004. Available from: <https:// onlinelibrary.wiley.com/doi/abs/10.1111/j.1939-165X.2004. tb00342.x>. Accessed: Mar. 20, 2018. doi: 10.1111/j.1939165X.2004.tb00342.x.

MEURS K.M. et al. Comparison of polymerase chain reaction with bacterial $16 \mathrm{~s}$ primers to blood culture to identify bacteremia in dogs with suspected bacterial endocarditis. Journal of Veterinary Internal Medicine, v.25, p.959-962, 2011. Available from: <http://onlinelibrary.wiley.com/doi/10.1111/j.19391676.2011.0742.x/full>. Accessed: Nov. 23, 2016. doi: 10.1111/j.1939-1676.2011.0742.x.

O'DWYER et al. The detection of microbial DNA but not cultured bacteria is associated with increased mortality in patients with suspected sepsis a prospective multi-centre European observational study. Clinical Microbiology and infection. v.23 p.208, 2017. Available from: <https://doi. org/10.1016/j.cmi.2016.11.010>. Accessed: Jan. 10, 2018.
PAOLUCCI M. et al. Conventional and molecular techniques for the early diagnosis of bacteraemia. International Journal of Antimicrobial Agents, v.36, p.6-16, 2010. Available from: $<$ http://www.ncbi.nlm.nih.gov/pubmed/21129933>. Accessed: Nov.23, 2016. doi: 10.1016/j.ijantimicag.2010.11.010.

QUINN, P.J. et al. Clinical veterinary microbiology. Spain:Wolfe, 1994, p 648.

SALIMNIA $H$ et al. Evaluation of the film array blood \& culture identification panel: results of a multicenter controlled trial. Journal of Clinical Microbiology v.54 p.687-698, 2016. Available from: $\quad<$ http://jcm.asm.org/content/54/3/687.full $>$. Accessed: Jan. 11, 2018. doi: 10.1128/JCM.01679-15

SAMBROOK J.J. \& RUSSELL W.D. Preparation and analysis of eukaryotic genomic DNA. In: Molecular cloning A laboratory manual. New York, USA. 2001, Vol 1, Chapter 6 p. 6.8 .

SINGER M. et al. The third international Consensus Definitions for Sepsis and septic shock (Sepsis 3). JAMA, v. 315 p. 801810, 2016. Aviable from: <https://www.ncbi.nlm.nih.gov/ pubmed/26903338>. Accessed: Nov. 27, 2017. doi:10.1001/ jama.2016.0287.

WHITE T.J. et al. Amplification and direct sequencing of fungal ribosomal RNA genes for phylogenetics. In: Innis M.A., Gelfan D.H., Sninsky J.J., White T.J. (eds) PCR Protocols: A Guide to Methods and Applications, Academic Press, San Diego. 1990 p. 315-322. Available from: <https:// nature.berkeley.edu/brunslab/papers/white1990.pdf $>$. Accessed: Jan. 31, 2018. 